Thomas Faist

Jürgen Gerdes

Beate Rieple

\title{
Dual Citizenship as a Path-Dependent Process
}

Arbeitspapiere - Working Papers

No. 7, 2004 
Thomas Faist, Jürgen Gerdes and Beate Rieple: Dual Citizenship as a Path-Dependent

Process - Bremen: COMCAD, 2004

(Working Papers - Center on Migration, Citizenship and Development; 7)

The COMCAD Working Paper Series is intended to aid the rapid distribution of work in progress, research findings and special lectures by researchers and associates of COMCAD. Papers aim to stimulate discussion among the worldwide community of scholars, policymakers and practitioners. They are distributed free of charge in PDF format via the COMCAD website.

The opinions expressed in the papers are solely those of the author/s who retain the copyright. Comments on individual Working Papers are welcomed, and should be directed to the author/s.

University of Applied Sciences Bremen

Center on Migration, Citizenship

and Development (COMCAD)

Neustadtswall 30, 28199 Bremen

Telefon: +49 (0)421 59054285

Telefax: +49 (0)421 59064286

Homepage: http://www.comcad-bremen.de 


\section{Contents}

Abstract

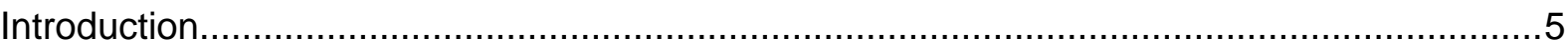

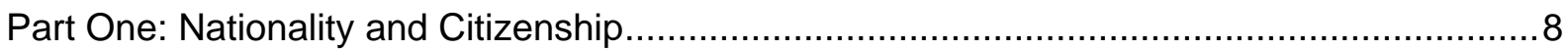

Part Two: Towards a Description of Dual Nationality as a Path Dependent Process ..............9

Part Three: Two Perspectives on Dual Nationality - Postnational and National ...................10

Part Four: The Postnational Perspective - Nationality as a Human Right .............................12

Part Five: National Variations in Integrating Nations and Immigrants ................................15

Outlook: Dual Nationality and Master-Mechanisms of Political Change ............................25 


\title{
Dual Citizenship as a Path-Dependent Process ${ }^{1}$
}

\begin{abstract}
Over the last few decades dual nationalities worldwide have increased rapidly. This is astonishing when one considers that a few decades ago citizenship and political loyalty to a national political community were considered inseparable. Overall, there has been a bumpyline trend towards increasing tolerance. Yet, the degree to which dual nationality is tolerated by states differs. Based on the findings of postnational and national perspectives, the analysis proposes to view tolerance and resistance towards dual nationality as a pathdependent process. The questions dealt with are: What are the factors encouraging the generally increasing tolerance towards multiple nationalities? How can cross-national differences regarding de jure and de facto tolerance towards dual nationality be explained? The main tendency over the past decades has been the growing emphasis on individual rights vis-à-vis state prerogatives in liberal democracies. The expansion of de jure tolerance towards dual nationality has part of inter-, supra- and national-level developments, which are connected to diverse factors such as gender equity, understandings of nationhood, immigrant incorporation and general characteristics of the political systems.
\end{abstract}

${ }^{1}$ The editors of this volume and Aristide R. Zolberg provided helpful criticism. Thomas Faist also wishes to thank the School of International Migration and Ethnic Relations (IMER) at Malmö University, where he spent the Spring of 2003 as the Willy-Brandt-Guestprofessor.

Forthcoming in Alejandro Portes \& Josh de Wind (eds.), Conceptual and Methodological Developments in the Study of International Migration, Special Issue of International Migration Review (2004). 


\section{Introduction}

Over the last few decades the number of cases of multiple nationalities worldwide has increased rapidly, and for various reasons this is being tolerated by more and more sovereign states. This is astonishing when one considers that a few decades ago citizenship and political loyalty to a specific national political community, were considered inseparable. Dual citizenship is thus a particularly interesting case for studying the prerequisites and contexts for policies directed at immigrants and politics around immigration issues. Nonetheless, the degree to which dual nationality is tolerated by states differs widely. The questions then are: What are the factors encouraging the increasing tolerance towards multiple nationalities? How can national differences regarding de jure and de facto tolerance towards dual nationality be explained?

Generally speaking, the proponents of dual nationality in immigration states argue that state authorities need to create favorable conditions for the political integration of newcomers. They emphasize the individual rights necessary for successful incorporation. In a nutshell, the proponents of dual nationality insist, first, on the importance of social integration. This claim hinges on the observation that those states tolerating dual nationality have had, ceteris paribus, proportionally more immigrants naturalizing. In political debates, dual nationality and thus citizenship - understood as the set of institutionalized ties between the governed and the governing, which are based upon social and symbolic ties among citizens - is also justified as a mechanism to enhance political participation of immigrants, or to motivate political representatives to take into account immigrants' interests, along with other tools such as political rights for resident non-citizens viz. denizens (e.g. Jones-Correa, 1998). Second, those in favor of tolerating dual citizenship point to the requirement of congruence between the people and the resident population. Thinking on citizenship has traditionally assumed some kind of congruence between the people (demos), state territory and state authority (cf. Jellinek, 1964:406-27). Ideally, citizens are the basic law-givers in a democratic society. The addressees of a law should see themselves as its authors (cf. Rousseau, 1966; Habermas, 1992). Third, according to a multicultural perspective, border-crossing ties of persons should or could be tolerated as constituting specific cultural resources which citizens with an immigrant background hold (Gerdes, 2000). Such transnational resources form part of the cultural repertoire which immigrants may need to act successfully in public life (cf. Kymlicka, 1995). This argument is found less often in public debates and academic discourse; probably because it is contested whether cultural rights as such could also form the basis for new divisions among citizens contradicting the notion of equal democratic citizenship (cf. Offe, 1998). 
In contrast to the proponents of dual nationality who uphold the enabling function of states for immigrant incorporation, critics, first, emphasize that the individual migrants themselves need to adjust to the new political environment. They focus on the obligations of naturalizing immigrants who have to give proof of their readiness to adapt and to be loyal to the new state by renunciation of their previous nationality. Second, on the duty side of citizenship, dual nationality involves multiple loyalties and links of citizens across state borders or even within a world society. This has a direct bearing on issues such as dual military service and double taxation and thus pertains to state sovereignty. Third, and more importantly, dual citizenship raises the fundamental question if political membership across borders in democratically legitimated states can be designed in a way that it upholds the feedback loops between the governed and the governing. It is thus a question of democratic legitimacy and equal political rights. Empirically, we observe that national citizenship has developed over time in territorially enclosed, socially relatively coherent and inter-generationally viable political communities with effective state authorities (cf. Rokkan and Urwin, 1983). Ties of citizens reaching into multiple states seem to question the supposed congruence of the demos, the state territory and the state authority and, in particular, violate basic principles such as 'one person, one vote'. It could lead to a certain degree of incongruence between demos and state authority because dual citizens could exert voice but still exit at will when the political outputs and outcomes do not suit them. One might ask whether loyalty and trust among citizens (cf. Putnam, 1993:ch. 6) are divisible. Multiple loyalties are often seen to damage the public spirit. Fourth, dual nationality may also create problems of output legitimacy (Easton, 1967), if dual citizens withdraw from certain obligations or are seen to endanger national security. In those cases, dual nationality could give further incentives to populist politics.

Nonetheless, the tolerance towards dual nationality is still increasing. In order to capture this truly seminal development, we need to expand our conceptual horizon and go beyond nationally-bound political systems to include a postnational perspective. ${ }^{2}$ This is one way to counter "methodological nationalism" (Hermenius Martin, 1974, quoted by Smith, 1979:191) in comparative political studies which has unduly privileged politics in national states, as if these systems could be thought as tightly bounded political containers. In short, national and postnational perspectives are necessary to give a satisfactory account of the development and consequences of dual citizenship in the context of immigrant policies and political

2 The ongoing project "Multiple Citizenship in a Globalising World: Germany in Comparative Perspective" aims towards a more comprehensive analysis of the politics of dual citizenship in Europe. This project, which is housed at the University of Applied Sciences Bremen, is funded by the Volkswagen Foundation (2002-2005). The research compares the politics of three immigration countries - Germany, Sweden and the Netherlands - and two emigration countries - Turkey and Poland. The analysis in this article draws on results from the immigration countries. 
incorporation. It means that each perspective is useful for explaining different parts of the puzzle: The postnational perspective on the extension of personhood rights vis-à-vis states highlights either the devaluation of national citizenship or the gradual extension of nationality as a human right, and the national perspective on political incorporation is helpful in accounting for variations in tolerance across national states. The results from both perspectives point in the same direction: in legal cases and legislation the rights of citizens and persons have gained in importance vis-à-vis considerations of state sovereignty.

Methodologically, we propose to use the notion of path-dependency to trace the seminal trend towards an uneven yet clearly increasing tolerance of dual nationality in liberal democracies. The concept basically means that once political actors have started to move along a certain path - tolerating dual nationality under certain circumstances such as children out of bi-national marriages - there is every incentive to continue along the same way and serious disincentives exist to reverse course. The original incentives for starting down the path may arise out of different contexts, e.g. dual nationality as a tool for social and political integration in immigration countries, or dual nationality as a means used by emigration country governments to maintain the loyalty of expatriates (cf. Glick-Schiller and Levitt, this volume). ${ }^{3}$

The first part defines the key terms nationality as a normative-legal notion, on the one hand, and citizenship as a normative-political concept, on the other hand. The second outlines the methodological tools of path-dependency. The third part sketches the two conceptual perspectives for analyzing dual citizenship: postnational and national. The fourth lists the factors which have led to a growing tolerance of dual nationality worldwide over the past decades and thus deals with state sovereignty. This includes an analysis of nationality as a human right, in this case the implications of international conventions for national law. The fifth part describes national variations in the de facto and de jure tolerance or even acceptance of dual nationality, ranging from a continuum from restrictive to liberal cases. The main purpose is to discern factors which account for nationally-specific modes of dealing with multiple nationality in Germany, the Netherlands, and Sweden. The concluding section then identifies some of the crucial mechanisms of path-dependency which have driven both tolerance and resistance towards dual nationality in particular and citizenship in general over the past decades.

\footnotetext{
${ }^{3}$ It is certainly no coincidence that many emigration states have also changed their laws to permit dual nationality even upon naturalization in an immigration country. Other measures include the renaturalization of former citizens and eased access to property and heritage for former citizens. Such countries include Mexico, Turkey, Tunesia, El Salvador, Colombia and the Dominican Republic (cf. Freeman and Ögelman, 1998).
} 


\section{Part One: Nationality and Citizenship}

Contested dual nationality implies the importance of citizenship as full membership in a political community. Nationality means full membership in a state and the corresponding tie to state law and subjection to state power. The interstate function of nationality is to clearly define a people within a relatively clearly delineated territory and to protect the citizens of a state against the outside, at times hostile, world. The intrastate function of nationality is to define the rights and duties of members. According to the principle of domaine reservée exclusive competence, each state decides within the limits of sovereign self-determination on the criteria required for access to its nationality. One general condition for membership is that nationals have some kind of close ties to the respective state, a genuine link (Rittstieg, 1990:1402).

Citizenship, in contrast, essentially comprises three mutually qualifying dimensions: first and foremost, the notion of collective self-determination and democracy, second, the legally guaranteed status of equal political freedom and other rights and, third, membership of a political community. First, citizenship means above all the principle of unity of both governing and being governed, whatever form the democratic procedures of each state take in detail. Citizens endowed with equal political liberty obey the laws in the creation of which they participated and to whose validity they thus consent (Walzer, 1989). Without democratic procedures guiding citizens' political self-determination, citizenship would only amount to members of political communities being subjects of a sovereign. Second, the constitutions of modern states enshrine human and fundamental rights of liberty belonging to citizenship as a legal status. In general, citizens' rights fall into various realms, for example, civil or negative rights to liberty, political rights to participation such as the right to vote and to associate, and social rights - which in the Anglo-Saxon context not only means the right to social benefits in case of sickness, unemployment and old age, but in particular also the right to education (Marshall, 1964). It is highly contested whether, to which degree and for which category of citizens cultural or even group-differentiated rights should be a constitutive part of citizenship. The duties corresponding to citizens' entitlements are the duty to serve in the armed forces in order to protect state sovereignty toward the exterior, while the duty to pay taxes, to acknowledge the rights and liberties of other citizens and to accept democratically legitimated decisions of majorities structure the internal sphere (cf. Habermas, 1992:371). Third, citizenship rests on an affinity of citizens to certain political communities, the partial identification with and thus loyalty to a self-governing collective. The qualifications required of citizens of modern national states is an affinity to their political community - often a nation (cf. Weber, 1972:242-244) or a multi-nation - that is, identification with a self-governing collective that is able to establish a balance between the individual and common interests on 
the one hand and rights and responsibilities within the political community on the other. Affiliation to a collective, expressed as a set of relatively continuous, social and symbolic ties of citizens otherwise anonymous to each other, is linked to the status dimension because citizenship means the formalization of reciprocal obligations of members in a political community, akin to a social treaty (Dahrendorf, 1992:116). By means of laws and official norms, government institutions hold in trust networks of reciprocity and collectives of solidarity, which cannot be produced by the state itself.

Nationality and citizenship are intricately related. The underlying argument here is that changing state-citizen relations and also state-denizen ties (cf. Motomura, 1998) have implications for the growing tolerance towards dual nationality. In international law, for example, nationality is increasingly seen as a human right. And on the national level, rights of non-citizens, in particular permanent residents viz. denizens in social science parlance (Hammar, 1990), have increased and changed the discourse on citizenship. One result has been that in countries such as the Netherlands and Sweden, dual nationality was discussed as an alternative to extending local voting rights for permanent residents from the local to the national level.

\section{Part Two: Towards a Description of Dual Nationality as a Path Dependent Process}

Globally, the tolerance towards dual nationality has increased steadily over the past few decades, albeit at a very uneven pace. The factors driving this growing tolerance point towards changes in basic factors enabling and structuring immigrant political incorporation in many immigration countries. To draw on a metaphor used for immigrant assimilation, this 'bumpy-line' (Gans, 1992) trend towards increasing tolerance constitutes a path-dependent development. There is no reason to suppose that the development of dual citizenship has to unravel as if ushered along by some historical teleology, a charge often advanced against T.H. Marshall's triadic stages of the subsequent development of civil, political and social rights. Nonetheless, there is evidence to surmise that citizenship has been shaped by significant developmental pressures.

To describe the growth of tolerance towards dual nationality as a path-dependent development means to specify the 'positive' feedback effects - what economists call "increasing returns" -driving this development (Pierson, 2000). The basic idea here is that once collective actors such as states and state organizations have started down a track, the costs of reversal are very high. There will be other choice points, however, at which decisions have to be taken. A path-dependent effect occurs when a previous decision, norm or rule reinforces itself, when it determines in part the subsequent development of events. 
Decisions taken by national states and international organizations, over time, limit the range of available options at subsequent points. In so doing, they may encourage continuity in the form of retention of the original choice. ${ }^{4}$ In this analysis, the concept of path dependency is used to both uncover the main factors contributing to overall global trend towards growing tolerance of dual nationality in the postnational perspective and to identity the factors which explain the divergent paths selected immigration states have taken in this respect in a national perspective.

\section{Part Three: Two Perspectives on Dual Nationality - Postnational and National}

The growing interest in citizenship beyond the traditional understanding of territorial and exclusive liberal democratic states has been accompanied by the discussion of two noteworthy aspects. First, political issues and decisions migrate beyond national borders, and second, persons are perceived to be crossing state borders on a new scale (cf. Castles, this volume). In the national and more traditional perspective, however, the question of dual citizenship is predominantly defined as a problem pertaining to individual states and immigrant integration, while from the postnational perspective, dual citizenship is characterized as a result of international cooperation of national states. From a postnational point of view it is related to rights and democracy beyond the national state.

\section{The Postnational Perspective: Dual Citizenship as a Transitory Phenomenon}

The postnational concept comes in at least two variants: postnational membership and supranational citizenship. Postnational membership focuses on the impact of interstate norms upon citizenship in sovereign states. Supranational citizenship asks about the rights of citizens in multi-level governance systems such as the European Union (EU).

4 The political-economic notion of path-dependence has a sociological counterpart, cumulative causation. Both concepts can be described by using the metaphor of a "funnel" in which, once an actor such as a state has taken certain decisions, it eliminates, by that very act, other possible courses of action. For example, a twenty-year-old college student has a wide range of possible career options at his fingertips which are not available to a forty-year-old professor who has heavily invested in that career path. Thus the concept of cumulative causation is similar to the notion of pathdependence which is based upon the stable equilibrium concept in economics. Yet, unlike pathdependency, which searches for the choices and consequences of processes, locked into a certain pattern, cumulative causation focuses on the very context and mechanisms that makes spiraling effects possible. Thus the concept of cumulative causation is a specific form of analyzing presumed causalities (Maruyama, 1962:175). In short, path-dependency seems to be more concerned about the choices of actors and their consequences while cumulative causation emphasizes processes that enable spiraling processes (positive feedback loops) or return to the original state of affairs (negative feedback loops). Here, the focus is on choices and results, not so much on the endogenous dynamics of and spiraling effects. 
Postnational Membership: The main idea is that two of the three main components of citizenship - in the postnational membership concept simply rights \& duties and collective identity - have increasingly decoupled over the past decades. Thus, for example, human rights, formerly tightly connected to nationality, nowadays also apply to non-citizen residents. In other words, settled non-citizens also have access to significant human, civil and social rights. Therefore, nationality as the 'right to have rights' is not anymore the fundamental basis for membership in political communities. Instead, discourses tied to international norms, such as the various charters on fundamental rights by the United Nations and the EU, are supposed to contribute to postnational citizenship or membership (Soysal, 1994). However, some postnational concepts primarily emphasize the devaluation of nationality and national citizenship and its replacement by a set of rights pertaining to personhood. It does not identify the international and supranational developments which underpin the emergence of nationality as a human right, overlooking the fact that rights accorded to non-citizens have repercussions for access to nationality. Also, this perspective cannot comprehend the democratically legitimated part of citizenship status and the importance of affective ties to and within states, i.e. the first dimension of citizenship discussed before. It is thus no coincidence that analysts often speak of postnational membership instead of citizenship. The popular legitimation of membership in political communities, of utmost importance for any democratic regime, gets lost. Instead, the focus is on courts who uphold interstate norms "rights across borders" (Jacobson, 1995). The very basis of equal political liberty is neglected by the postnational membership concept. For example, the tension of political rights attached to both denizenship and citizenship is not considered.

Supranational Citizenship: This concept primarily concerns citizenship in political multi-level systems such as the EU. At first sight, supranational citizenship appears as the logical next step in the centuries-old evolution of citizenship in what nowadays are liberal democracies. It is a current process much alike the one by which sovereign states have gradually centralized and assimilated local and regional citizenships over the past centuries. Over the past decades, this has occurred under propitious political-economic conditions, such as continued prosperity and the absence of war, and under the umbrella of a sort of a proto-federal system, the EU. The formidable obstacles on the road to substantive EU citizenship include the acceptance of democratic majority decisions and supranational social policies, and the resources necessary for the integration of political communities, such as trust and solidarity (cf. Delanty, 1996:6). European Union citizenship, as it has developed since the Treaty of Maastricht (1991), is not coterminous with dual citizenship, overlapping several sovereign states. Rather, it is a sort of multiple citizenships nested on several governance levels regional, member state and supranational. Only citizens of a member state are citizens of the 
Union (Faist, 2001). Yet in such a supranational perspective dual citizenship is ultimately of secondary importance only. It is only a transitory step to European citizenship.

The National Perspective: Dual Nationality as a Mechanism of Immigrant Integration As a sort of anomaly, citizens living abroad belong to territorially and inter-generationally bounded political communities. It is no coincidence that many countries are usually more tolerant towards multiple nationalities of their own citizens living abroad if compared to immigrant newcomers in their territory. Nevertheless, in a national perspective there may be plausible reasons for tolerating or even accepting dual citizenship. The most persuasive is that dual citizenship increases the propensity among newcomers viz. immigrants to naturalize in the country of settlement. Some empirical surveys suggest that immigrants prefer maintaining their old citizenship when naturalizing in another country (cf. Chavez, 1997:131).

\section{Part Four: The Postnational Perspective - Nationality as a Human Right}

When viewed from a postnational perspective, nationality has gradually emerged as a human right over the past decades. Supranational integration within the EU has furthered this trend. This meant, for example, that dual nationality has become one of the means to combat statelessness for categories such as refugees. Also, the legal norm of gender equity has ensured that dual nationality has spread. More specifically, the right of independent nationality for married women and the opportunity of either parent to pass on nationality to their children have left their mark. Supranational developments further show how postnational and national levels are interlinked, such as mutual recognition of nationalities within member states of the European Union. Such measures make it increasingly harder to exclude immigrants from so-called third countries from dual nationality within national states. As several cases suggest, such as Sweden, Switzerland and the Netherlands, granting dual nationality to nationals abroad makes it harder to exclude immigrants from the same benefits.

The postnational perspective is most useful in outlining crucial inter- and supranational background factors conducive to the tolerance towards dual nationality. While the conventional postnational membership perspective suggests a decoupling of rights and identities linked to the citizenship status and asserts the increasing salience of rights attached to personhood, the empirical study of dual nationality adds an additional interpretation. Retaining the focus on personhood, one may usefully trace the emergence of the right to nationality as a human right, instead of emphasizing the importance of human 
rights discourses on denizenship rights. This has gone hand in hand with a growing change in legal perspectives concerning states and citizens. Whereas half a century ago the judiciary prioritized the state's perspective when passing judgment on the genuine link persons entertain toward states (e.g. the famous Nottebohm case in 1955), international courts have increasingly begun to shift attention to the rights of persons.

Nationality as a human right at first sight challenges the traditional notion of state sovereignty, as expressed in the notion of domaine reservée. According to this principle, every state has the sovereign right to determine the criteria for acquiring the nationality of that state. Traditionally, there are few matters which were more a symbolic expression of state sovereignty than the internationally recognized right of states to determine nationality. A few decades ago, most states on earth agreed that multiple nationalities should be avoided as best as possible. The preamble to the Hague Convention reads: "All persons are entitled to possess one nationality, but one nationality only." (League of Nations, 1930) State laws, bilateral treaties - such as the famous Bancroft Treaties the USA concluded with European countries around the middle of the $19^{\text {th }}$ century - and interstate conventions such as The Hague Convention of 1930 and the European Convention on the Reduction of Multiple Nationality (Council of Europe, 1963) all bear testimony to this dominant belief. The rights and duties of states versus citizens were built on the assumption of the congruence of an almost holy trinity of territory, people and political regime (Montevideo Convention of 1933). The only conditions attached to the international recognition of a nationality have been that (1) it is related in a certain way to the legal system of the state in question, that (2) a socalled genuine link exists between the state citizen and the respective state, and that (3) the self-determination of other states is likewise respected. Further restrictions may only arise out of international agreements. While these conventions did not carry the more binding character of international regimes, such as the fledgling human rights regime, they guided sovereign states' declared policies.

In concrete terms, two rules dominated law and state practice from late $19^{\text {th }}$ century until the Cold War. First, acquiring a new nationality meant losing the previous one. Most states automatically excluded a citizen from membership when this person acquired the nationality of another state, or when other signs suggested that a citizen expressed loyalty to a foreign potentate - for example, serving in its army or voting in elections (Spiro, 1997). Political commentators used to connect dual citizenship to treason, espionage and a whole range of subversive activities. In many cases, countries of immigration required release from the original nationality upon naturalization. Second, since dual citizenship could never be avoided completely, some states dealt with the actual increase in multiple nationalities by 
providing for an optional rule. Upon reaching majority age the respective person had to choose one of the two nationalities. Otherwise, he or she risked to be expatriated (cf. BarYaacov, 1961).

However, there has been a gradual and lengthy but fundamental shift from exclusive state sovereignty to the increasing recognition of the legitimate claims and rights of individuals. Particularly the post-World War Two human rights norms in international law have significantly constrained the states "sovereign prerogative paradigm" in nationality law (cf. Kimminich and Hobe, 2000). Of course, a significant expression of this change is Art. 15 of the Universal Declaration of Human Rights (1948) according to which "[e]veryone has the right to nationality". This article recognizes nationality as the precondition for effective individual rights. This provision, at least initially, only meant a minimal constraint of state sovereignty, because thereby no particular state is required to grant the right to citizenship. Like the right to emigration, the individual right to change one's nationality is essentially of a negative kind. Furthermore, nationality as a human right has found its way only into one of the major human rights treaties adopted in the era after World War Two, namely the American Convention on Human Rights (1969); upheld by the Inter-American Court of Human Rights (1988). Because states were reluctant to relinquish their right to determine the conditions of their nationality, in the International Covenant on Civil and Political Rights (1966) in Art. 24, para. 3 only children were given the right to acquire a nationality.

Nevertheless, there are meaningful international conventions and treaties, judgments of international courts and evaluations of nationality laws through intergovernmental organizations, which have strengthened the individual right to citizenship in several respects against the claims of states to define exclusively the rules of their nationality laws. Especially relating to the issues avoidance of statelessness and securing of gender equality, there have been more far-reaching conclusions in respect to the individual right to citizenship. Examples include the Convention on the Reduction of Statelessness in 1961; the Conventions on Dual Nationality by the Council of Europe in 1963, 1977, and 1997; the Convention on the Nationality of Married Women in 1957; and the Convention on the Elimination of All Forms of Discrimination against Women in 1979. In sum, states' regulations bearing on nationality can no longer be deemed within their sole jurisdiction but are circumscribed by their obligations to ensure the full protection of human rights (Chan, 1991).

Also, supranational political integration has slowly increased tolerance towards dual nationality. Dual citizenship could be said to have an auxiliary function smoothing the road to European citizenship. For example, European integration has fostered the mutual recognition of multiple citizenships in the member states. For example, Germany does not require 
citizens of other member states to ask for release from their former citizenship when acquiring German nationality. Dual citizenship could thus be envisioned as a bridge between national and supranational citizenship.

In sum, the evidence suggests that dual citizenship is not simply a foreboding of cosmopolitan citizenship. The main trend has been the spread of dual nationality and the tolerance towards dual citizenship as a result of an emerging trend of nationality as a human right. Importantly, the very principles national states have enshrined in their constitutions and agreed upon in international conventions, regimes and institutions have found their way back to shape legislation on nationality and the practices of citizenship.

\section{Part Five: National Variations in Integrating Nations and Immigrants}

The extension of denizenship status and cultural pluralism in many western European countries since the 1970s has also brought the question of political rights and the franchise to the fore. This has been helped by developments identified through the postnational perspective, the emergence of nationality as a human right and rights for denizens. Dual nationality has become one of the legitimate means to achieve the congruence between the resident population and the demos. In those countries where dual nationality became a matter of political debate and legal regulation, efforts to advance social integration and to thus extend the franchise to non-citizens on the local and national level preceded those on multiple nationalities. Mostly, social integration policies favorable to dual citizenship were of a multicultural kind. These culturally pluralist policies have, at least discursively, expanded the range of legitimate ties immigrants may hold.

This comparative sketch probes into the question of why we observe different degrees of de jure tolerance towards dual nationality across European states. Over the past years, a great many immigration states have made naturalization less and less dependent upon release from their former nationality. This trend clearly pervades nationality laws and regulations. Examples include France in 1973, Portugal in 1981 and Italy in 1992. Others have only made minor concessions, such as Germany. Yet even those national states who, in principle, strive to avoid dual nationality, usually have some exempting rules. In general, such regulations apply when the former state refuses to release the citizen from nationality, or makes the release dependent upon unreasonable conditions; for example, the rule that young men need to serve in the army before being discharged from nationality. The analysis suggests that nationally-specific modes have shaped the politics surrounding the varying degrees of tolerance of dual citizenship found in the respective countries. 
As to the cases selected, there are two ways of classifying tolerance and restriction towards dual nationality. The first is to look at states' de jure toleration vs. restriction towards dual nationality. The second is to analyze the de facto behavior of states. Fundamentally, dual nationality arises when children are born in countries where the ius soli principle holds, while the countries of their parents' origin apply the ius sanguinis principle. Also relevant for de facto tolerance is when states are indifferent to dual nationality for various reasons. For example, despite the 'oath of allegiance', the USA does not require written evidence that immigrants have actually renounced a previous nationality. Other countries such as the UK do not even regulate dual nationality (Hansen, 2002). Here, the analysis focuses on the de jure dimension. The comparative analysis includes Germany, the Netherlands and Sweden. These three countries have varying policies on the acceptance of dual citizenship and can be classified accordingly on a continuous scale ranging from restrictive to tolerant and, finally, open. The most restrictive cases are characterized by the following criteria:

(1) Assignment by birth: only one nationality possible;

(2) Obligation to choose a nationality on reaching maturity;

(3) Renunciation requirement (in some cases also proof required) upon naturalization in another country; and

(4) Forced expatriation upon naturalization in another country.

The more stringently the acquisition of a nationality corresponds to the principles (1) to (4), the more restrictive the regime - and conversely, the more lenient the procedure, or the more exemptions there are from these requirements, the more open the regime in question is to dual citizenship. The most important form of de jure tolerance in this respect is the abolishment of the renunciation requirement.

Of the three immigration countries, Germany is the most restrictive de jure, the Netherlands more tolerant, and Sweden has followed in 2001, now being the most liberal. Although the recent extension of the ius soli clause in Germany's nationality legislation is extremely generous in comparison to that of other European states, the principle of avoiding dual citizenship is de jure to be adhered rather strictly. The individuals in question must, by the end of their $23^{\text {rd }}$ year, opt for one or the other nationality, and may otherwise be deprived of their German nationality. As before, in the case of naturalization - apart from the special case of late repatriates of German origin (so-called ethnic Germans or Spätaussiedler) - the relinquishment of the previous citizenship is generally required. Nevertheless, several exceptions apply, for example, when there are overriding constitutional grounds, or if there 
are no provisions for the relinquishment of the nationality of the other country in question, or if it is refused or obstructed. ${ }^{5}$ For a while during the early 1990s in the Netherlands, dual nationality was tolerated without exception on naturalization, but the relinquishment of the prior nationality is now generally required again. Compared with Germany, however, there are much more extensive exemption clauses. In Sweden, by comparison, dual citizenship is now accepted in general. Sweden previously belonged to the restrictive category and demanded the relinquishment of the previous nationality (Figure 1).

The propositions guiding the cross-national analysis ${ }^{6}$ are the following:

(1) The respective understandings of nationhood and explicit culturally pluralist policies directed at immigrants are decisive factors. A republican understanding of nationhood ${ }^{7}$ tends, at a minimum, to foster indifference towards dual nationality. However, it is questionable to which extent the ethno-cultural vs. republican distinction is applicable to the countries concerned. Second, for de jure tolerance of dual nationality to take hold, culturally pluralist

${ }^{5}$ In general, the reality of law has been more tolerant than the letter. For example, there are crude estimates that more than a quarter up to one third of all those naturalized in Germany in the 1970s and 1980s - apart from ethnic Germans - kept their former citizenship and thus were dual citizens. In 2000 , already more than $40 \%$ of all naturalisations in Germany occurred under maintenance of the original citizenship. In the Netherlands, the tightening of the rules in 1997 did not significantly affect the share of persons who kept their original citizenship. In 1996, 80 percent of those persons who naturalized retained the original citizenship. In 2000, after the re-installation of the renunciation demand, the proportion still amounted to 77 percent (de Hart, 2003).

6 The summary of the German case is based on the studies of Faist et al. (2003b and 2003c); the Swedish case draws on the work by Spång (2003); and the analysis of the Dutch case rests on de Hart's (2003) analysis.

${ }^{7}$ A republican understanding of nationhood is based on the premise that government in a republic is in principle the common business (res publica) of the citizens, conducted by them for the common good. The concept of nation is focused on a state (Staatsnation), in which citizens run their own affairs. Inclusion of all permanent residents into the nation and thus nationality is seen as a basis for public mindedness. Access to nationality is based on the subjective avowal of loyalty of individuals to the nation. In this sense republicanism strives to ensure an optimum of equal opportunities regarding political participation for all those (permanently) residing in the territory of a state. According to this definition, republicanism does not necessarily mean that public affairs should take precedence over the citizens' private life. An ethnic understanding of nationhood also holds that government is based on popular consent and participation. Yet, in contrast to a republican understanding, the nation is focused on the idea of a common culture (Kulturnation); historically even preceding statehood. Inclusion into the nation is traced to common descent, cultural traditions or lineage. There is less scope for persons for making their own decisions on the issue of nationality. Political participation and opportunities are seen and interpreted as an issue of intergenerational continuity. 
viz. 'multicultural' ${ }^{8}$ policies and discourses are also supportive, especially if connected with republican elements. Culturally pluralist policies towards immigrants have steadily gained in importance in European countries of settlement over the past decades (cf. Brubaker, 2001). The tolerance towards dual nationality is coupled tightly with the enfranchisement of immigrants in their role as denizens or citizens. The two factors overlap in cases such as the Netherlands and Sweden, where local voting rights and dual nationality have been seen, at times, as part of minority or multicultural policies; inspired by an integrative understanding of nationhood.

(2) The eventual legislative output is decisively mediated by nationally-specific modes of politics which form part of broader institutional - legal and political - opportunity structures and prevail in the field of immigrant integration, such as competitive party politics in Germany, corporatist consensus politics in Sweden, and a slowly eroding elite consensus in the Netherlands.

\section{Germany: Competitive Party Politics and Mainstream Populism}

The most recent changes in German nationality law which went into effect in 2000 facilitated the naturalization of foreign citizens who have lived in Germany for a certain length of time, and the automatic acquisition of German nationality by birth for the second and third generations - i.e. the extension of the principle of descent (jus sanguinis) and the principle of naturalization based upon socialization of young persons by the application of the principle of territoriality (jus soli). Another major issue of the debate was whether as a rule naturalization required the relinquishment of an individual's previous nationality or whether multiple nationalities should be tolerated to a greater degree than before. The chancellor of the new Red-Green governing coalition announced that new nationality legislation would make Germany 'compatible with Europe'. Interestingly, after a short and highly politicized public debate in early 1999, the rules for including the second generation were more liberal than demanded by the government while dual nationality was not allowed as a rule. However, by

${ }^{8}$ Multicultural policies are based on the assumption that a person's possibility to uphold her own cultural traditions, language and religion is crucial to personal identity and self-confidence and therefore a precondition for successful economic, social, cultural and political integration. Multicultural policies include various forms of public support for immigrant organisations and their cultural practices, the provision of the immigrant languages in schools and rights concerning their religious freedom and practices. Assimilationist policies, by contrast, aim towards the melting of immigrants into the majority core of an immigrant state viz. society. No special provisions for immigrants are desirable in the political or cultural realm in order to foster their integration into the mainstream. 
adding the jus soli rule, the German government added impetus to the de facto growth of multiple nationalities.

The run-of-the-mill explanation for Germany's lag in adopting a more liberal nationality law has been that the so-called ethno-cultural concept of nationhood presented a formidable obstacle (cf. Brubaker 1992). This argument not only neglects changes in German political culture since 1945, disregards the division of Germany until 1989 and the subsequent speedy reforms of nationality law, such as the introduction of as-of-right naturalization in 1993. It is also not supported by an analysis of parliamentary and public discourses on nationality legislation during the 1990s. There is not much evidence for explicit references to an ethnic or cultural understanding of citizenship among the opponents of dual nationality. Quite to the contrary, the opponents have consistently called for strengthening the renunciation rule for German citizens living abroad - at odds with an ethno-cultural understanding of nationhood. Moreover and ironically, tolerance towards dual nationality has been higher under the old nationality law dating back to 1913 (RuStAG) than in the subsequent reforms in 1977, 1991 and 2000. A factor directly impinging on the prospects for increasing de jure tolerance towards dual nationality has been the discursive use of 'multiculturalism'. While Germany would score somewhat lower than the Netherlands or Sweden regarding actually existing culturally pluralist policies towards immigrants (e.g. Rath and Groenendijk, 2000), it is also crucial that in political debates 'multiculturalism' has been elevated to become the polar and negatively loaded opposite to Germany not being a 'country of immigration' position in academic and political debates during the 1980s and 1990s. Indirectly, multiculturalism entered the citizenship debate only as a dystopic vision, when the opposition Christian Democrats (CDU/CSU), which opposed increasing tolerance dual nationality, succeeded in tying nationality to allegedly mounting immigration.

To connect dual nationality to issues of immigration, crime and security and thus treat it as a meta-issue, i.e. far remote from the political issue at hand, has been helped by extremely contentious party politics. This type of politics has largely determined the political opportunity structures regarding immigrant insertion. Since the 1970s, immigration and nationality issues have - intermittently - served as rallying posts for center right parties. Thus, mainstream parties have selectively used populist strategies in party competition. In the debate on dual nationality, the CDU instigated a signature campaign against dual citizenship. It proved very successful; more than 5 million signatures against the proposed new citizenship law. Ultimately, it was one of the main reasons for the defeat of the Social Democratic and the Green parties in the state elections in Hesse in early 1999. 
The Netherlands: Slowly Eroding Elite Consensus

Debates on dual nationality partly developed out of earlier efforts to enfranchise nonnationals in the 1970s and 1980s. During the 1970s, self-appointed advocates of immigrants started to push for local voting rights for non-citizens. In the 1980s, a majority of political parties hoped that enfranchisement could serve as a symbolic means to show that the government was responding to the need to improve the social position of non-nationals; responding to events such as the Moluccan train hijacking in 1974 and subsequent violent incidents. Local voting rights, instituted in 1985, were considered part of 'minority policies' meant to advance social integration of immigrants. Policy makers justified both local voting rights and dual nationality (1991-97) with the claim that they would ease social integration and serve as tools for immigrant incorporation. Individual rights were meant to accompany incorporation policies aimed at immigrant groups along established institutional structures of representation and consultation in the political, social and religious spheres. This approach was helped by the tradition of pillarization (verzuiling) which could be applied to immigrants as well. In the late 1980s, it became clear that a left-right coalition for an extension of the franchise for denizens to the national level was impossible because liberal and right-wing parties blocked. Subsequently, the discussion on political insertion turned to dual nationality. Dual citizenship also entered debates as a result of the realities of gender equity which were to be accepted. Since the 1960s women did not follow the status of their husbands automatically. And since the mid-1980s Dutch fathers and mothers could pass on nationality to their children, both in the Netherlands and abroad. In effect, this led to a de facto increase in dual nationality. Finally, the renunciation requirement was abolished and dual nationality practically accepted in 1991. However, the policy changed back again in 1997, now demanding renunciation of the former nationality naturalizing immigrants. Accordingly, formal citizenship law was changed in 2000, and came into effect in 2003. Nonetheless, when compared to more restrictive cases such as Germany, more exceptions still persist. The current law still accepts formal ties to more than one country acceptable for categories such as spouses in mixed marriages, children born of mixed marriages and second generation immigrants.

The Dutch case suggests that conceptions of the nation and nationhood have been changing constantly and in tandem with understandings of immigrant integration. In the Minderhedennota of 1983 - the government report initiating 'minority policies' - the Dutch nation was portrayed as a territorially bounded multiform viz. multicultural society. The Nota Integratiebeleid of 1994 reflected the policy shift away from cultural to socio-economic and from collective to individual concerns. This report used the dominant image of a Dutch nation 
built around an autochthone core, open to the rest of the world. This latter document and the Allochtonenbeleid of 1989 manifest a change in immigrant insertion policy, a move from 'minority policy' of the 1980s to 'integration' or 'allochtonen' policy, also called inburgerungspolicy. Interestingly, the concept of citizenship emerged as the leading principle of the 'new version of the persons of different cultures in the Netherlands' (Groenendijk and Heijs, 1999). The focus shifted from cultural pluralism to individual responsibility as a means to advance integration of the immigrant categories considered problematic, i.e. Surinamese, Moroccans and Turks. Language and civics courses for immigrants have since then become dominant integration schemes.

Unlike Germany, politicians and political parties in the Netherlands agreed to keep immigration out of political campaigns until the late 1990s. This was possible because of a consensus among the political elite of keeping contentious issues out of public debates. One of the most visible outcomes was the 1991 law. It emerged as a political compromise between the main political parties. How much immigrant integration policy dominated the reasoning on nationality rules can be seen in the fact that the legislators did not discuss or consider the issue of multiple bonds to several states. Instead, not surprisingly, the formula was to improve the legal position of immigrants in order to foster social integration. However, as it became visible that social problems among certain immigrant categories persisted, politics became more contentious and the elite consensus began to erode. As in the German case, the main political parties fell into two blocks. The Social Democratic PdVA and the left liberal D66 continued to favor tolerance, while the conservative-liberal VVD and the Christian CDA demanded to uphold or reinstall the renunciation demand. The main ideological fault line was the use of naturalization as a way to stimulate the social integration of immigrants. Since the mid-1990s other issues have also been brought into the public arena, such as dual loyalties and immigrants as calculating citizens who collect passports. Thus the issue of dual nationality has increasingly become part of a politicized discussion on immigrant insertion.

\section{Sweden: Socio-political Nationhood and Political Equality - Consensus Politics}

Like in the Netherlands, the Swedish debate emerged out of discussions on social integration policies. More specifically, the discussion on dual nationality started as a continuation of voting rights for resident non-citizens. After the government granted local voting rights in 1975, advocates of immigrant rights demanded to extend enfranchisement to the national level. While this proposal encountered strong opposition, dual nationality entered political debates as an alternative to voting rights for non-citizens. This discursive window widened in 
the mid-1980s, when the government instituted a parliamentary commission to explore opportunities for dual nationality. Yet most parties rejected the proposal. In 1990, the Social Democrats suggested to explicitly allow multiple nationality. The governing Center-Right government blocked and withdrew the proposition. Their stance shifted when yet another government commission on citizenship began to with nationality and citizenship in broad terms in 1997. This time it was the commission which asked the government for permission to propose changes in dual citizenship. While the multicultural rhetoric of the mid-1970s had been discarded by that time, the principle of political equality and, above all 'freedom of choice' (valfrihet) for immigrants, were very much alive and enjoyed widespread majority support among politicians and the populace. Freedom of choice concerned the right of immigrants to choose whether to retain their cultural tradition, hence forming the linchpin of multiculturalism in its 1970s version. By the late 1990s freedom of choice had become part of so-called 'integration policies'. Moreover, one of the most widely discussed arguments in favor of accepting dual nationality was the principle of gender equity. Gradually, from the 1950s onwards - in accord with international law - the principle of gender equity became more important than avoiding multiple nationalities. Also, fair treatment of Swedish citizens naturalizing abroad and immigrants naturalizing in Sweden played a role in the discourse. In 1979 the Swedish government took steps to allow Swedish citizens to acquire other nationalities without renouncing their Swedish citizenship. However, that was not fully recognized and put into practice until 2001.

In terms of the understanding of nationhood and its importance for nationality and citizenship, Sweden is a clear example of how restrictive and misleading the republican vs. ethno-cultural dichotomy can be. For the Swedish case, a sociopolitical understanding of citizenship, usually referred to by the shorthand of the 'people's home', is important for understanding both immigrant policies in general and citizenship politics and policies in particular. In the past, the 'people's home' was a way to envision and mobilize support for the social democratic welfare state project. It also has often been taken as a shorthand description of the welfare state program in Sweden more generally. There are various interpretations of its meaning. The first implies a scheme of social cooperation between citizen-workers, built around accommodations between capital and labor and other interest organizations and parties. Although the 'people's home' may be seen to carry elements of an ethno-cultural understanding of nationhood - cultural cohesiveness enabling strong social solidarity and reciprocity on a national level - it can also be interpreted as a break with ethno-cultural forms of nationalism and geared towards social inclusion on the basis of political equality and freedom. A second interpretation hinges on the articulation of Swedishness on the one hand, and the differentiation between the normal and the pathological, on the other hand. This form 
of the 'people's home' nationalism was especially prevalent at the turn of the $19^{\text {th }}$ and $20^{\text {th }}$ century, as evidenced by policies towards the Saami and the Roma. These latter groups, along with immigrants, became the targets of multicultural policies in their first phase during the late 1970s. The socio-political connotations of the 'people's home', especially those regarding the first interpretation, may have made it easier to introduce dual nationality. Regarding policies of cultural pluralism, dual nationality could be cast as an extension of the freedom of choice principle stemming from the 1970s. In 2000, it was beneficial to apply this principle to citizenship because dual nationality does not involve contentious group rights but pure and simple individual rights.

As to the institutional opportunity structure, Swedish politics in general and immigrant accommodation politics in particular have occurred between consensus politics with a focus on seeking broad societal and political majorities on the one hand and block politics of the left and the center right parties on the other hand. Although, as in the German case, no rightwing populist party of national importance existed, mainstream parties, unlike the German case, refrained from exploiting the citizenship issue in a populist fashion. In addition to consensus politics, this characteristic further contributed to the fact that the dual nationality issue never sparked heated public debates and strong media attention. As to the discursive opportunity structure, it is remarkable how strong the argument of political equality was in the discussions of the 1980s and 1990s. It was applied to equal treatment of Swedish citizens acquiring abroad and denizens naturalizing in Sweden - but also to more arcane and indirect arguments about the minimal difference in rights between denizens and citizens: since this difference was already so small, it would make little sense not to tolerate dual nationality.

\section{Preliminary Lessons from the Comparative Analysis}

The comparative analysis has profound implications for our understanding of nationality and citizenship politics. In general, there is convergence in the de facto tolerance (jus soli principle) and de jure tolerance (e.g. arising out of international law such as gender equity) towards dual nationality, on the one hand. However, the incorporation processes in all three countries analyzed differ substantially. This is obvious in rules relating to the relaxation of the renunciation requirement. This observation confirms the conclusion that immigrant incorporation policies in European countries have both converged and remained distinct along particular national patterns (cf. Freeman, this volume). 
Overall, the evidence presented suggests that politically inclusive understandings of nationhood coupled with explicit multicultural or minority policies and political rights for permanent residents have established a favorable context for increasing tolerance towards

dual nationality. Yet, there are three more specific findings. First, the classical dichotomy of republican vs. ethno-cultural concepts of nationhood and its significance for naturalization rules have to be re-examined and specified. Not only are such understandings subject to historical change, as the German case would suggest. More important, this distinction does not capture the specific mix of republican and ethnic understandings of nationhood which are relevant for understanding citizenship. As the Dutch and Swedish cases make clear, for example, socio-political interpretations of nationhood connected to welfare statehood have been decisive for legislation on nationality. Also, classical republican understandings of nationhood, such as the ones found in France and the USA, may foster indifference towards dual nationality (de la Pradelle, 2002 on France and Renshon, 2001 on the USA). Yet more explicit forms of recognition of dual nationality can be found in countries not typically associated with classical republicanism, such as Sweden. In general, politically inclusive understandings of nationhood in the liberal democracies analyzed are path-dependent factors which have changed over time but are not easily reversed. The choices that flow into the construction of such understandings have usually taken decades to crystallize.

Second, this finding indicates that other sets of factors, such as culturally pluralist policies may play a role. This means that understandings of national integration viz. nationhood usually have to be examined in conjunction with political rights for permanent residents and the prevailing modes of immigrant policies, ranging from multicultural to assimilationist policies. In two of the cases considered - Sweden and the Netherlands - debates and conflicts around dual nationality arose out of efforts to further enfranchise denizens, i.e. to extend the franchise for certain categories of non-citizens from the local to the national level. And even in Germany the first legislative efforts to deal with multiple nationalities (1993) came in the aftermath of a failed attempt by two northern German Länder to introduce local voting rights for permanent residents. This finding indicates that dual nationality has to be interpreted as part of the broader question of which political rights should be granted to immigrants and in what sequence. The general trend towards an extension of rights to noncitizen immigrants, which can be observed in Western Europe and North America since the 1960s, has led to a renewed discussion of political rights for non-citizens, and citizenship as a tool towards integration or a result of integration. Also, it has opened the question whether political citizenship rights such as the franchise on the national level should also be accessible to denizens (cf. Aleinikoff and Klusmeyer, 2002:ch.3). While the jury is still out on 
this question, it seems evident that rights for permanent residents have gradually strengthened and contributed to discussions on the extension of political rights for immigrants. This is another example of a gradual shift from a state-centric perspective on citizenship to a person-centered view; not engendered simply by international law but primarily arising out of constitutional principles in liberal democracies. This development is also part of discourses and actual policies surrounding explicitly multicultural policies directed at immigrants. Both political rights for denizens and dual nationality have been conceived as part of minority policies in the Netherlands during the 1980s and multicultural policies in Sweden during the second half of the 1970s and during the 1980s. While the labels for such policies may have changed, the substance has remained intact.

Third, however, the Netherlands and Sweden accepted dual nationality de jure at a time when multicultural rhetoric was on the wane and were gradually replaced by discourses on individual responsibility and citizenship. Dual nationality thus seems to be a substitute for explicit minorities or multicultural policies. This is not surprising because nationality and citizenship are concepts predicated on individual and not on collective rights. The latter are often seen in public and academic debates - rightly or wrongly - as main ingredients of multicultural policies. Arguments in favor of tolerating dual citizenship in reform debates, which emphasized the legal recognition of border-crossing social and symbolic ties of persons, have often taken recourse to multicultural ideas. The shift from multicultural to nationality and citizenship policy also suggests that citizenship has emerged as a common denominator for immigrant political insertion. This is true for countries such as Sweden and the Netherlands, and for more classical republican countries such as France and the USA. Also, in Germany, the draft for a new immigration law provided for education in civics as one of the central instruments for integrating newcomers. In sum, dual citizenship has become part of the trend towards a revalorization of full political membership in many immigration countries, and the resurgence of the 'good citizen', who is nowadays often conceived in a communitarian way.

\section{Outlook: Dual Nationality and Master-Mechanisms of Political Change}

In the case of dual nationality, we can identify two mechanisms engendering path-dependent effects. In particular, lock-in and disincentive mechanisms and their effects have resulted in the 'stickiness' of the policy path. 
First, the lock-in mechanism means that certain options are rendered almost wholly unattainable by the original choices made. Examples are norms such as gender equity or jus soli. The German Constitutional Court considered in 1974 dual nationality as an "evil" in principle. Nevertheless, in terms of gender equity, it maintained that nationality can be transferred to children by the father and the mother. The jus soli rule in the USA has traditionally been interpreted as emanating from the $14^{\text {th }}$ Amendment to the Constitution. Therefore, a change of qualification of the principle would require either another Constitutional Amendment or a far-reaching reinterpretation of the clause (cf. Aleinikoff and Klusmeyer, 2002:12). Taken together, these two principles have resulted in a pervasive growth of dual nationality in the attribution of political membership by marriage, birth and family formation. It is hard to imagine that such principles will be reversed because they are partly enshrined in national constitutions and international conventions. Second, a disincentive effect means that original choices make future options not impossible but deeply unattractive to policy-makers. For example, while efforts aiming at multicultural policies towards immigrants are prone to reversal, policy-makers often have not done so. Instead, they have relabeled 'multicultural' into 'integration' policies without a change in substance in Sweden, or refocused efforts from politico-cultural 'minority' policies to socio-economic 'integration' policies in the Netherlands. Moreover, the pervasive growth of rights of permanent residents viz. denizens has put the issue of political rights for non-citizens as a means of incorporation on the table.

However, path-dependent developments are not immune to reversal. In general, this means that choice points and alternatives exist (North, 1990:98-9). In principle, there are two mechanisms which could lead to a reversal, exogenous shocks and learning. First, it is easy to imagine that factors exogenous to the law and politics of nationality and citizenship impinge on their development. The most obvious are armed conflicts between national states which form international migration systems. Although historical comparisons need to be handled with utmost care, it is suggestive that during World Wars One the public loyalties of immigrants became a matter of concern. More recent wars between immigration and emigration countries and September 11 have renewed public debates about the loyalty of immigrants (Faist, 2003). For instance, dual nationality has been discussed in the Netherlands as a means to expel undesired citizens of immigrant background. After all, they still have nationality of at least one other country (cf. de Hart, 2003).

The second mechanism - 'learning' - can be easily observed. The Dutch case is particularly instructive in this regard. For some years during the 1980s, the franchise for denizens and 
dual nationality were seen as instruments of overall immigrant integration, even beyond the political realm. Later, however, some parties declared the focus on cultural minority policies a failure and, in essence, the emphasis of public policies shifted to socio-economic integration into labor and housing markets. Concomitantly, during the 1990s, goals such as the congruence of the resident population and the people and instruments such as dual nationality became more contested, as criteria such as the alleged effectiveness of incorporation policies - output legitimacy - gained in importance. Learning in this case reflected a growing skepticism towards minority policies which, among other things, implied collective rights for immigrant groups. Ironically, dual nationality - the relaxation of the renunciation requirement - served as a tool to continue cultural pluralist policies in the publicly more acceptable frame of individual rights.

The spread of dual nationality as a path-dependent process may very well continue. This is especially likely under the propitious circumstances of supranational integration in regional governance structures such as the EU. Seen in this way, the increasing tolerance towards dual nationality may well be interpreted as part of a centuries-long expansion of rights for citizens and denizens in states characterized by some form of rule of law. On the international level, this is signaled by a growing tendency to interpret nationality as a human right and to apply provisions favoring gender equity. On the national level, rights for permanent residents which approach those of citizens also point towards an increasing emphasis of individual rights vis-àvis state sovereignty. The driving forces which enabled lock-ins to emerge have to be sought in group conflicts (cf. Tilly, 1996). These conflicts are, as in the case of social rights, not simply be found in working class strength but also preventive elite counterstrategies, the most well-known outcome of which is the Bismarckian welfare state. Given the absence of formidable immigrant political strength in virtually all European immigration countries, the increasing tolerance towards dual nationality is clearly a symbolic effort by ruling elites to accommodate immigrants and to live up to international norms. The political conflicts and discourses around dual citizenship have been shaped by reference to established yet changing understandings of nationhood and immigrant incorporation, political cultures and constitutional principles.

In this analysis the path-dependent view has been primarily used to explain cross-national differences. Yet this concept could also be applied to describe convergent processes of increasing toleration reaching across the national states described. The relevant mechanism could be called a democratic proliferation. Liberal democracies tend to face this dilemma when adhering to the principle of avoiding dual nationality as far as possible. Because of the importance of individual rights, liberal democracies are compelled to accept dual nationality upon naturalization if the respective other state makes renouncing nationality impossible, or 
imposes unreasonable demands. Also, liberal democracies tend to accept dual nationality in the name of gender equity when nationality is acquired by birth. Furthermore, such states may be inclined to grant dual citizenship within regional governance systems such as the EU. But once some exceptions have been granted, new interpretations of individual rights and new claims of other categories of persons combined with court cases could easily lead to a further increase of exceptions. This could result in a proliferation of 'exception groups'. The more exceptions and thus potential claimant groups, the greater the likelihood that questions of legitimating different treatment arise because each exemptions have to be justified on reasonable grounds. Problems of justification and rising costs of administrative procedures may well lead to a general tolerance of dual citizenship on the long run. In the rather restrictive German case, for example, it is not unlikely that unequal treatment as a consequence of the so-called 'option model' (cf. Figure 1) could result in increased tolerance. Most probably, the Federal Constitutional Court will have to decide whether this clause can be upheld.

In a sanguine view, one possible long-term outcome is that dual nationality could serve as a bridging construct for supranational and multilayered forms of political membership. Immanuel Kant once drew attention to the alternative of a "federation of free republics" on the level of states to avoid the twin dangers of global tyranny, on the one hand, and the anarchy of sovereign states, on the other (Kant, 1970). Applied to the case at hand, dual nationality would interface the world of states and the world of societies by institutionalizing the border-crossing, overlapping social and symbolic ties among citizens and between citizens and states. Seen in this way, dual citizenship as overlapping political membership does not constitute a break with the Westphalian system of state sovereignty (cf. Ruggie, 1993) - but may be a mechanism in post-Westphalian systems such as the European Union to advance the integration of national and supranational forms of membership in political communities. Indirectly, the nationally distinct modes of immigrant political incorporation would then continue to be shaped by varying yet increasing degrees of tolerance towards and even acceptance of dual nationality.

It is by no means clear, however, that such an optimistic perspective is warranted. The key assumption behind such an optimistic scenario, namely a rather peaceful state system, is historically contingent, applicable to certain regions of the world only, and continuously changing. The postnational perspective has only focused on international law and transnational discourses, forgetting much of the 'hard' factors of the international state system. Much of the future course of border-crossing citizenship would depend on the development of national states and the international system of states. In other words, social integration of immigrants on the national level also depends on the interactions among the 
system of states, an aspect of international system integration (cf. Hollifield, this volume). Outside the OECD world, statehood has by no means developed along the successful Western model of governance in territorially bounded, rule-of-law, democratic and interventionist entities. And it is an open question whether statehood in the OECD world continues along the path taken after World War Two. At the very least, a comprehensive analysis of the course of (dual) citizenship needs to take into account the international system and the states within migration systems, thus moving beyond the myopic concern with major Western immigration countries. 


\section{REFERENCES}

Aleinikoff, A. and D. Klusmeyer

2002 Citizenship Policies for an Age of Migration. Washington, D.C.: Carnegie Endowment for International Peace.

Bar-Yaacov, N.

1961 Dual Nationality. New York: Praeger.

Brubaker, W.R.

1992 Citizenship and Nationhood in France and Germany. Cambridge, MA: Harvard University Press.

Brubaker, W.R.

2001 "The Return of Assimilation? Changing Perspectives on Immigration and its Sequels in France, Germany, and the United States," Ethnic \& Racial Studies, 24 (1): 531-548.

Chan, J.M.M.

1991 "The Right to a Nationality as a Human Right. The Current Trend Towards Recognition," Human Rights Law Journal, 12 (1-2): 1-14.

Chavez, P.L.

1997 "Creating a United States-Mexico Political Double Helix: The Mexican Government's

Proposed Dual Nationality Amendment," Stanford Journal of International Law, 33: 119-151.

Council of Europe

1997 European Convention on Nationality and explanatory report, November 6, 1997. ETS No. 166. Strasbourg: Council of Europe Publishing.

Dahrendorf, R.

1992 "Citizenship and the Modern Social Conflict," In 1688-1988. Time for a New

Constitution. Ed. R. Holme und M. Elliot. Basingstoke: Macmillan, 112-125.

Delanty, G.

1996 Inventing Europe: Idea, Identity, Reality. Houndmills: Macmillan Press.

Easton, D.

1967 A Systems Analysis of Political Life. New York: Wiley. 
Faist, T.

2000 The Volume and Dynamics of International Migration and Transnational Social Spaces. New York: Oxford University Press.

Faist, T.

2001 "Social Citizenship in the European Union: Nested Membership," Journal of Common Market Studies 39 (1): 39-60, 2001

Faist, T.

2003 The Migration-Security Nexus. International Migration and Security before and after 9/11. Malmö University. School of International Migration and Ethnic Relations (IMER), WillyBrandt-Working Paper Series, No. 3/2003.

Faist, T., J. Gerdes, and B. Rieple 2003a: Global Conditions Favoring Tolerance Towards Multiple Citizenship. Working Paper No. 1, University of Applied Sciences Bremen, International Studies in Political Management (ISPM).

Faist, T., J. Gerdes, and B. Rieple

2003b Concepts of Nationhood and Multiculturalism in Immigrant Integration: The Case of Germany. Working Paper No. 2, University of Applied Sciences Bremen, International Studies in Political Management (ISPM).

Faist, T., J. Gerdes, and B. Rieple

2003c Arguments and Belief Systems on Integration and Dual Citizenship: The Case of Germany. Working Paper No. 3, University of Applied Sciences Bremen, International Studies in Political Management (ISPM).

Freeman, G.P. and N. Ögelmann

1998 "Homeland Citizenship Policies and the Status of Third Country Nationals in the European Union," Journal of Ethnic and Migration Studies 24: 769-788.

Gans, H.J.

1992 "Second-Generation Decline: Scenarios for the Economic and Ethnic Futures of the Post-1965 American Immigrants," Ethnic and Racial Studies 15 (2):173-192.

Gerdes, J.

2000 "Der doppelte Doppelpass - Transstaatlichkeit, Multikulturalismus und doppelte Staatsbürgerschaft." In Transstaatliche Räume. Politik, Wirtschaft und Kultur in und zwischen Deutschland und der Türkei. Ed. T. Faist, Bielefeld: transcript, 235-298. 
Groenendijk, K. and E. Heijs

1999 "Einwanderung, Einwanderer und Staatsangehörigkeitsrecht in den Niederlanden von 1945 bis 1998." In Politische Integration der ausländischen Wohnbevölkerung. Ed. U. Davy. Baden-Baden: Nomos, 105-145.

Habermas, J.

1992 Faktizität und Geltung. Frankfurt/M.: Suhrkamp.

Hammar, T.

1990 Democracy and the Nation-State. Aliens, Denizens and Citizens in a World of International Migration. Aldershot: Gower.

Hansen, R.

2002 "The Dog that didn't Bark: Dual Nationality in the United Kingdom." In Dual Nationality, Social Rights and Federal Citizenship in the U.S. and Europe. Ed. R. Hansen and P. Weil. New York: Berghahn Books, 179-190.

de Hart, B.

2003 Dual Nationality in the Netherlands. Unpublished Manuscript. University of Nijmegen, Centre of Migration Law.

Jacobson, D.

1995 Rights Across Borders: Immigration and the Decline of Citizenship. Baltimore: Johns Hopkins University Press.

Jellinek, G.

1964 [1905] System der subjektiven öffentlichen Rechte. Reprint of the 2nd edition (1919). Jones-Correa, M.

1998 Between Two Nations. The Political Predicament of Latinos in New York City. Ithaca: Cornell University Press.

Kant, I.

1970 [1781] “Perpetual Peace. A Philosophical Sketch." In Kant's Political Writings. Ed. H. Reiss. Cambridge, MA: Cambridge University Press, 93-130.

Kimminich, O. and S. Hobe

2000 Einführung in das Völkerrecht. $7^{\text {th }}$ edition. Tübingen: Francke. 
Kymlicka, W.

1995 Multicultural Citizenship. A Liberal Theory of Minority Rights. Oxford: Oxford University Press.

League of Nations

1930 Treaty Series, Convention on Certain Questions Relating to the Conflict of Nationality Laws, April 12, 1930. Treaties and International Engagements Registered with the Secretariat of the League of Nations. Vol. 179, no. 4137 (1937-1938).

Marshall, T.H.

1964 Class, Citizenship and Social Development. Essays by T.H. Marshall. New York: Anchor Books.

Maruyama, M.

1963 "The Second Cybernetics: Deviation-Amplifying Mutual Causal Processes," American Scientist 51 (2): 164-179.

Motomura, $\mathrm{H}$.

1998 "Alienage Classifications in a Nation of Immigrants: Three Models of 'Permanent Residence"', In Immigration and Citizenship in the $21^{\text {st }}$ Century. Ed. N.J. Pickus. Lanham, MD: Rowman \& Littlefield, 199-222.

North, D.C.

1990 Institutions, Institutional Change and Economic Performance. Cambridge: Cambridge University Press.

Offe, C.

1998 “'Homogeneity' and Constitutiona Democracy: Coping with Identity Conflicts through Group Rights", The Journal of Political Philosophy 6 (2). 113-141.

Pierson, $\mathrm{P}$.

2000 "Increasing Returns, Path Dependence, and the Study of Politics," American Political Science Review 94 (2): 251-267.

de la Pradelle, G.

2002 Dual Nationality and the French Citizenship Tradition. In Dual Nationality, Social Rights and Federal Citizenship in the U.S. and Europe. Ed. R. Hansen and P. Weil. New York/ Oxford: Berghahn Books, 191-214. 
Putnam, R. D.

1993 Making Democracy Work: Civic Traditions in Modern Italy. Princeton, NJ: Princeton University Press.

Rath, J. and K. Groenendijk

2001 Western Europe and Its Islam. Leiden: Brill.

Renshon, S.A.

2001 Dual Citizenship and American National Identity. Washington, D.C.: Center for Immigration Studies.

Rittstieg, $\mathrm{H}$.

1990 "Doppelte Staatsangehörigkeit im Völkerrecht," Neue Juristische Wochenschrift 43: 1401-1405.

Rokkan, S. and D.W. Urwin

1983 Economy, Territory, Identity: Politics of West European Peripheries. London: Sage.

Rousseau, J.-J.

1966 [1762]: Du contrat social: ou Principes du droit politique. Paris: Garnier.

Ruggie, J.G.

1993 "Territoriality and Beyond: Problematizing Modernity in International Relations," International Organization 47 (2): 139-174.

Smith, A.

1979 Nationalism in the $20^{\text {th }}$ Century. New York: New York University Press.

Soysal, Y.N.

1994 The Limits of Citizenship. Chicago: University of Chicago Press.

Spiro, P.J.

1997 "Dual Nationality and the Meaning of Citizenhip," Emory Law Review 46: 1411-1485.

Spång, M.

2003 Citizenship in Sweden: Reasons for Changing Citizenship Legislation. Unpublished Manuscript. Malmö University, School of International Migration and Ethnic Relations (IMER).

Tilly, C. (Ed.)

1996 Citizenship, Identity and Social History. International Review of Social History 40 (Supplement). 
Walzer, M.

1989 "Citizenship." In Political Innovation and Conceptual Change. Ed. T. Ball, J. Farr and R.L. Hanson. Cambridge: Cambridge University Press, 211-219.

Weber, M.

1972 [1922] Wirtschaft und Gesellschaft. 5th Edition. Tübingen: J.C.B. Mohr. 


\section{Figure 1: Access to Nationality in Germany, Sweden and the Netherlands (after 2000)}

\begin{tabular}{|c|c|c|c|}
\hline & Germany & Sweden & The Netherlands \\
\hline $\begin{array}{l}\text { As-of-right } \\
\text { naturalization }\end{array}$ & $\begin{array}{l}\text { after } 8 \text { years of residence; conditions } \\
\text { attached: no welfare dependency; language } \\
\text { test: evidence of sufficient knowledge of } \\
\text { German }\end{array}$ & $\begin{array}{l}\text { as-of-right after } 5 \text { years of residence ( } 5 \text { years for } \\
\text { citizens from non-Nordic countries; } 2 \text { years for } \\
\text { citizens from Nordic countries) }\end{array}$ & $\begin{array}{l}\text { as-of-right after } 5 \text { years of lawful residence; } \\
\text { conditions attached: ability to conduct a simple } \\
\text { conversation in Dutch was deemed sufficient } \\
\text { (until recently); criterion of "being } \\
\text { incorporated" did not play any role in practice; } \\
\text { now: language proficiency and citizenship } \\
\text { courses required }\end{array}$ \\
\hline $\begin{array}{l}\text { Second and } \\
\text { subsequent } \\
\text { generations }\end{array}$ & $\begin{array}{l}\text { jus sanguinis; jus soli, provided that one } \\
\text { parent has lived for eight years in Germany or } \\
\text { holds a permanent residence permit for at } \\
\text { least three years (since 2000); also: educated } \\
\text { in Germany for } 8 \text { years for second generation } \\
\text { (since 1991) }\end{array}$ & $\begin{array}{l}\text { jus sanguinis, coupled with socialization } \\
\text { principle for those born or raised in Sweden }\end{array}$ & $\begin{array}{l}\text { jus sanguinis \& limited form of jus soli: option } \\
\text { right (since 1984); foreign children born in the } \\
\text { Netherlands have an 'option right'; they can } \\
\text { acquire Dutch nationality by unilateral } \\
\text { declaration between the ages of } 18 \text { and } 25\end{array}$ \\
\hline $\begin{array}{l}\text { Dual } \\
\text { nationality }\end{array}$ & $\begin{array}{l}\text { accepted for ethnic Germans; and in specific } \\
\text { circumstances, such as economic loss } \\
\text { involved or when country of origin does not } \\
\text { allow expatriation; 'optional principle' if the } \\
\text { child obtains the parents' nationalit(ies), she } \\
\text { must give up the non-German or German } \\
\text { nationality before reaching the age of } 23\end{array}$ & $\begin{array}{l}\text { dual citizenship explicitly allowed since } 2001 ; \text { no } \\
\text { requirement to renounce former nationality; } \\
\text { before } 2001 \text {, the rules were as restrictive as in } \\
\text { Germany }\end{array}$ & $\begin{array}{l}\text { dual citizenship allowed as a rule (1991-97); } \\
\text { since then a wide range of exceptions; further } \\
\text { restrictions are now (2003) widely discussed }\end{array}$ \\
\hline
\end{tabular}

